\title{
Methyl and Total Mercury in Different Media and Associated Fluxes in a Watershed Forest, Southwest China
}

\author{
Hongxia Du ${ }^{1,2}$, Ming Ma ${ }^{1}$, Tao Sun ${ }^{1}$, Siwei An ${ }^{1}$, Yasuo Igarashi ${ }^{1,2}$ and Dingyong Wang ${ }^{1, *}$ \\ 1 College of Resources and Environment, Southwest University, Chongqing 400715, China; \\ duhx@swu.edu.cn (H.D.); maming@swu.edu.cn (M.M.); suntao81589@126.com (T.S.); \\ asw5713176@126.com (S.A.); aigara@mail.ecc.u-tokyo.ac.jp (Y.I.) \\ 2 Chongqing Key Laboratory of Bio-Resource for Bioenergy, Southwest University, Chongqing 400715, China \\ * Correspondence: dywang@swu.edu.cn; Tel.: +86-23-6825-1691
}

Received: 25 October 2018; Accepted: 19 November 2018; Published: 22 November 2018

\begin{abstract}
Mercury (Hg) deposition in the forest ecosystem is a significant source of input for methyl $\mathrm{Hg}(\mathrm{MeHg})$ and total $\mathrm{Hg}(\mathrm{THg})$ to the subtropical forest field and downstream aquatic systems. Wet deposition, litterfall, runoff, and fluxes with forest soil percolate of $\mathrm{MeHg}$ and $\mathrm{THg}$ were sampled for two years in a watershed forest of southwest China. Results showed that the depositions of $\mathrm{THg}$ and $\mathrm{MeHg}$ through litterfall and throughfall were $86 \mu \mathrm{g} \mathrm{m} \mathrm{m}^{-2} \mathrm{yr}^{-1}$ and $0.8 \mu \mathrm{g} \mathrm{m}^{-2} \mathrm{yr}^{-1}$ respectively, with litterfall acting as a predominant route for the input of both $\mathrm{THg}$ and $\mathrm{MeHg}$. The estimated fluxes of $\mathrm{THg}$ and $\mathrm{MeHg}$ in the throughfall and litterfall were 3 and 4 times greater than those in the precipitation. Methylmercury in the decomposed litter migrates during its erosion by surface runoff and the concentrations of $\mathrm{MeHg}$ were quite consistent with that in the surface runoff. Methylmercury mainly accumulated in the lower layer of the litter and upper layer of the soil $\left(O_{i}\right)$, and its transfer through the soil cross-section was delayed. $\mathrm{THg}$ retention was not consistent with $\mathrm{MeHg}$, probably with lower soil layers $\left(O_{e}\right.$ and $\left.O_{a}\right)$ storing and enriching THg in the forest ecosystem. The forest floor of the lower soil is an effective sink for THg but not for MeHg. Methylmercury accumulated in decomposing litter and upper soil layer might transfer with soil percolate, possessing potential ecological risks for residents living around the downstream aquatic systems.
\end{abstract}

Keywords: THg; MeHg; watershed forest; deposition; transport

\section{Introduction}

Mercury $(\mathrm{Hg})$ is a worldwide environmental contaminant that leads to the contamination of forest, soil, water, plants, snow, and others [1]. It is well accepted that elemental $\mathrm{Hg}\left(\mathrm{Hg}^{0}\right)$ can travel long distances in the atmosphere, impacting aquatic systems in remote regions through deposition [2-6]. Consequently, atmospheric deposition is regarded as the principal source of $\mathrm{Hg}$ input for remote pristine regions with rare anthropogenic $\mathrm{Hg}$ sources [7]. As a general rule, dry deposition, estimated as the sum of litterfall and throughfall minus open-field wet deposition, is more dominant than wet deposition of $\mathrm{Hg}$ [8]. Recent research shows that dry deposition is more important than wet deposition in North America over vegetated surfaces [9]. Wet deposition of $\mathrm{Hg}$ in the forest is different with the water surfaces and non-forested areas, being largely dependent on the forest types. Mercury cycling in the forest ecosystem received more attention in the past years because the forest field plays crucial roles in the terrestrial cycling of total $\mathrm{Hg}(\mathrm{THg})$ and methylmercury $(\mathrm{MeHg})$, acting as a link between the atmospheric and aquatic ecosystems $[10,11]$. Atmospheric $\mathrm{Hg}$ deposition is promoted in the forest system comparing with other ecosystems due to the large surface areas associated with canopy foliage. 
Moreover, the effective surface areas differ among different types of vegetation, leading to different deposition rates. The total atmospheric $\mathrm{Hg}$ deposition can be calculated by the fluxes of throughfall and litterfall [12]. THg levels in the throughfall under boreal forest canopy increase in northern American [13]. The evergreen broadleaf forest canopies have greater surface leaf areas and more surface roughness than the northern American forest, which contributes to slower air flow rate and elevated $\mathrm{Hg}$ input fluxes [14]. Therefore, it is hypothesized that more $\mathrm{Hg}$ from canopies possibly enters into the forest floor due to the dense canopies of the subtropical forest [14].

Simian Mountain belongs to a typical subtropical forest system located in Chongqing, southwest China. Its subtropical evergreen broadleaf forest is by far the world's largest and best- preserved forest near 28 degrees north latitude. Although strict controls on industrial emissions have resulted in a significant decrease in $\mathrm{Hg}$ levels and acid rain deposition in recent years, those changes may have a lagged impact over time. Besides the natural sources of $\mathrm{Hg}$ pollution, anthropogenic sources of Mt. Simian have considerably elevated because of artisanal gold-mining, fossil fuel combustion, as well as pharmaceutical, industrial and chemical applications, especially in booming China over the past 30 years [5,15-18]. Subtropical forests are characterized by higher forest coverage and dominant perennial evergreen trees. The forest coverage of the researched forest reaches $95.8 \%$, among which $98 \%$ is evergreen broadleaf forest, which makes it possess larger surface area to absorb more $\mathrm{Hg}$ [19]. Meanwhile, the sub-alpine water conservation forest is the most important drinking water protection site in China. Deposited Hg in the water conservation forest is redistributed by the forest canopies, litterfall and forest soils through infiltration and accumulation into the surface and subsurface runoff, thus providing essential water source for downstream aquatic ecosystems and local residents, especially among those in extreme poverty and remote areas in southwest China. Therefore, it is significant to research on $\mathrm{Hg}$ fate in a representative subtropical watershed forest, which is useful for evaluating the risk of $\mathrm{Hg}$ for residents living around the downstream aquatic systems.

Scientists have conducted extensive research in the past years in order to interpret the fate and transformations of $\mathrm{Hg}$ in the litterfall, throughfall, runoff and soils of watershed forests [20-22]. They found potential terrestrial sources of $\mathrm{THg}$ and $\mathrm{MeHg}$ in the runoff and the processes controlling the load of $\mathrm{Hg}$ from soil to the runoff, which indicated that the upland $\mathrm{Hg}$ output might possess certain ecological risk $[14,23,24]$. Our previous research also found that the forest runoff increased the output of $\mathrm{Hg}$ from the catchments of Mt. Simian, especially in summer after heavy rains [25]. However, little attention has been paid to the long-term studies on transformation and accumulation of $\mathrm{Hg}$ in different organic layers of the soils, and the final fate of $\mathrm{Hg}$ in the soil profiles. Therefore, there is a critical need to understand the fate and behavior of $\mathrm{Hg}$ in a watershed forest stand and evaluate the ecological risk of $\mathrm{Hg}$ to the local residents. Therefore, the objective of this study was to investigate the contribution of elevated atmospheric $\mathrm{Hg}$ deposition in a sub-alpine water conservation forest, and the potential $\mathrm{Hg}$ output fluxes to downstream aquatic ecosystems where $\mathrm{Hg}$ could accumulate to toxic levels in fish and other aquatic animals. On the other hand, we also aimed to investigate whether the differences in the behavior of $\mathrm{MeHg}$ and $\mathrm{THg}$ among different layers of the forest floor support the hypothesis that $\mathrm{Hg}$, especially the $\mathrm{MeHg}$, may be much easier to transport in the forest floor due to the dense canopies under the warm and watery subtropical climate and the regional elevated atmospheric Hg emission.

\section{Materials and Methods}

\subsection{Site Description}

Chongqing is located in the southwest of China's inland and the upstream of Yangtze River. Mt. Simian national nature reserve $\left(106^{\circ} 22^{\prime}-106^{\circ} 25^{\prime} \mathrm{E}, 28^{\circ} 35^{\prime}-28^{\circ} 39^{\prime} \mathrm{N}\right)$ is situated approximately $200 \mathrm{~km}$ away from urban Chongqing. The climate of Mt. Simian is predominantly subtropical humid monsoon, with a well-defined annual rain season from June to September. Annual average temperature and rainfall is $13.7^{\circ} \mathrm{C}$ and $1127 \mathrm{~mm}$ respectively. The evergreen broadleaf forest is one of the most 
representative and well-preserved vegetation types in Mt. Simian. More importantly, it is regarded as the sole extant, largest forest in the same latitude of the earth. Therefore, a secluded evergreen broadleaf forest stand without anthropogenic sewage was selected as our sample site (Figure 1).

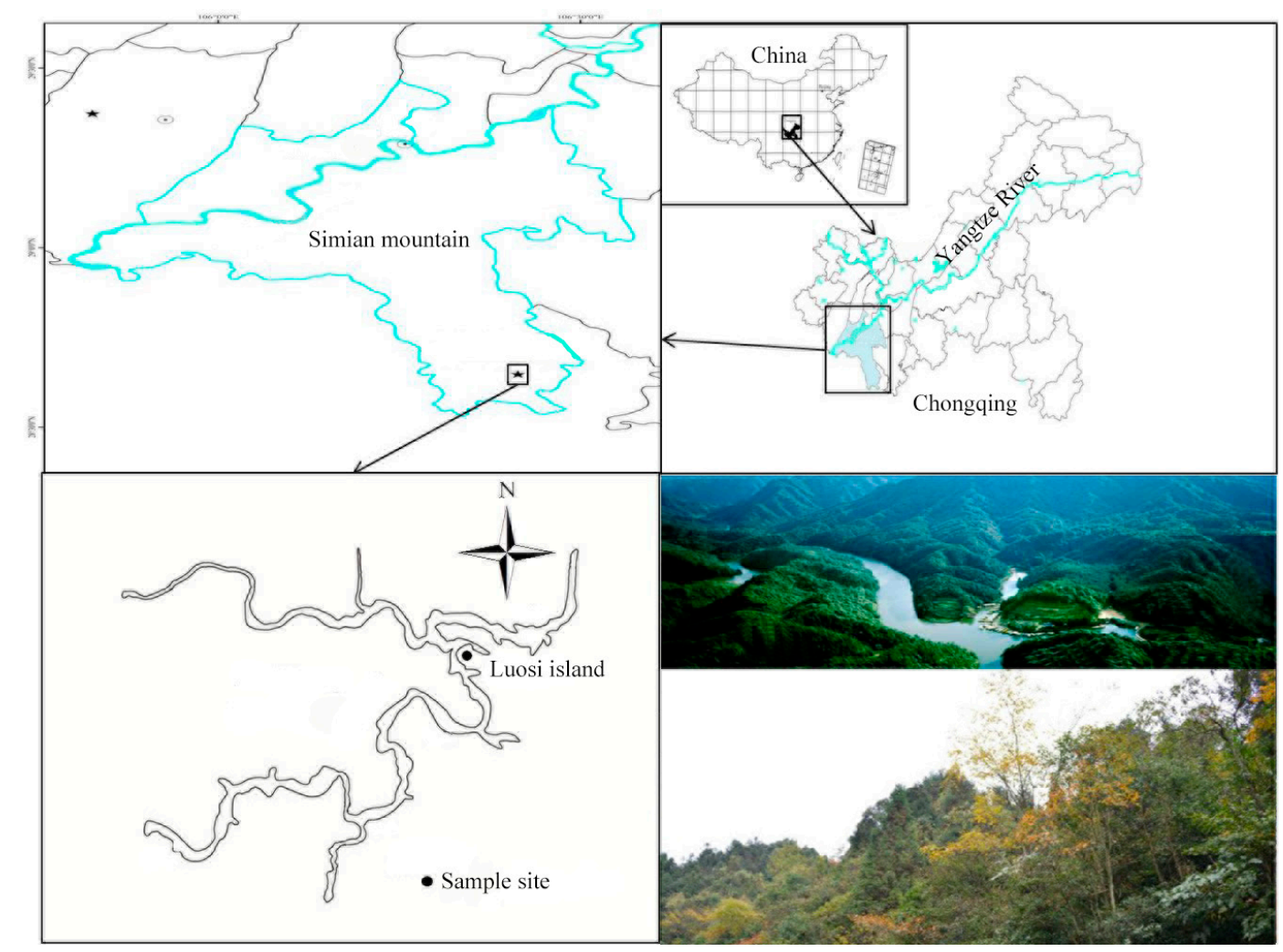

Figure 1. Schematic diagram of the study site, Mt. Simian in Chongqing, China.

\subsection{Sampling Method of Throughfall, Runoff and Soil Percolate}

The precipitations were collected by automatic precipitation samplers (APS-3A, Changsha Xianglan Scientific Instruments Company, Changsha, China) settled on an open forest field of the study site. The instrumental standards and the setting parameters of APS-3A were consistent with our previous research [26].

Three permanent observation plots $\left(20 \times 20 \mathrm{~m}^{2}\right)$ were selected to collect throughfall by self-made collectors, which consisted of acid-washed borosilicate glass bottle, protected by polyvinyl chloride covering systems, and wide-mouth Teflon funnel (20 cm in diameter). The collectors were sealed by polyethylene after each precipitation event, avoiding $\mathrm{Hg}$ dry deposition from falling into the sampling bottles. Subsequently, the sampled rain water at the three plots was mixed. The volume-weighted mean concentrations (VWM) were used to describe monthly $\mathrm{THg}$ and $\mathrm{MeHg}$ concentrations based on Equation (1).

$$
\mathrm{VWM}=\frac{X_{1} \times V_{1}+X_{2} \times V_{2}+\cdots+X_{t} \times V_{t}}{V_{1}+V_{2}+\cdots+V_{t}} .
$$

where $X_{t}$ is the concentration of $\mathrm{Hg}$ in each precipitation event $\left(\mathrm{ng} \mathrm{L}^{-1}\right), V_{t}$ is the volume of each rainfall (mm).

$\mathrm{Hg}$ fluxes were obtained by multiplying $\mathrm{Hg}$ concentrations by precipitation volume. Wet deposition fluxes of $\mathrm{THg}$ and $\mathrm{MeHg}$ were calculated based on Equation (2).

$$
F_{w}=\frac{1}{1000} \sum_{i=1}^{i=n}\left(C_{R}^{i} P^{i}\right)
$$


where $F_{w}$ means the annual THg or MeHg wet deposition fluxes $\left(\mathrm{mg} \mathrm{m}^{-2} \mathrm{yr}^{-1}\right), C_{i}$ means the VWM (ng $\mathrm{L}^{-1}$ ) of each rain sample, and $P_{i}(\mathrm{~mm})$ means the amount of precipitation or throughfall.

Five random sites for runoff were selected at the study area. In each site, the runoff at the interface of litterfall and soil were collected by five stainless steel water collection plates $(20 \times 20 \mathrm{~cm})$, and then transferred into borosilicate glass bottles $(1 \mathrm{~L})$ by Teflon pipes. During the sampling period, the runoff samples were collected every two weeks.

Forest-soil percolate was sampled below soil horizon of the forest floor with $9(15 \times 30 \mathrm{~cm})$ lysimeters which were made from pure, non-leaching food grade stainless steel. Forest-floor percolate solutions were sampled at 3 random locations near the throughfall collectors within the study plot, with three lysimeters at each location. At each of the three plots, the plate lysimeters were installed, namely three replicates underneath the $O_{i}, O_{a}$ and $O_{e}$ layers of the forest floor respectively. Prior to their installation in the field, the lysimeters were percolated with standard soil solutions of known $\mathrm{Hg}$ concentrations (Table 1). In order to make sure there were no memory effects, the lysimeters were installed in the soil more than three months before the beginning of the forest-floor percolate collections. Since the forest-soil percolate and element fluxes in the organic layer were limited, the water balance fluxes were adjusted by the annual budget of $\mathrm{Cl}^{-}$in the forest floor by the annual sum of weekly measured $\mathrm{Cl}^{-}$fluxes with throughfall [27], and obtained as mean values from five throughfall samplers at each of the three subplots.

Table 1. $\mathrm{THg}$ and $\mathrm{MeHg}$ concentrations in different layers of the forest floor.

\begin{tabular}{|c|c|c|c|c|c|c|c|}
\hline \multicolumn{2}{|c|}{ Layer } & $\begin{array}{c}\text { THg } \\
\left(\mathrm{ng} \cdot \mathrm{g}^{-1}\right)\end{array}$ & $\begin{array}{c}\mathrm{MeHg} \\
\left(\mathrm{ng} \cdot \mathrm{g}^{-1}\right)\end{array}$ & $\begin{array}{c}\text { Density (g } \\
\left.\mathrm{cm}^{-3}\right)\end{array}$ & $\begin{array}{c}\text { Thickness } \\
\text { (m) }\end{array}$ & $\begin{array}{c}\text { THg Content } \\
\left(\mu \mathrm{g} \cdot \mathrm{m}^{-2}\right)\end{array}$ & $\begin{array}{c}\text { MeHg Content } \\
\left(\mu \mathrm{g} \cdot \mathrm{m}^{-2}\right)\end{array}$ \\
\hline \multicolumn{2}{|c|}{ Litterfall } & $73.3 \pm 14.2$ & $0.86 \pm 0.4$ & $0.38 \pm 6.2$ & 0.21 & 5849.3 & 8.9 \\
\hline \multirow{3}{*}{ Soil } & $O_{i}$ & $315.5 \pm 27.3$ & $1.06 \pm 0.3$ & $1.37 \pm 2.1$ & 0.20 & 9509.1 & 31.9 \\
\hline & $\mathrm{O}_{e}$ & $408.6 \pm 42.2$ & $0.61 \pm 0.2$ & $1.54 \pm 5.9$ & 0.20 & $20,106.2$ & 30.1 \\
\hline & $O_{a}$ & $368.4 \pm 22.7$ & $0.26 \pm 0.2$ & $1.57 \pm 16.6$ & 0.20 & $25,449.1$ & 17.9 \\
\hline
\end{tabular}

$O_{i}$ means the upper soil with depth of $0-20 \mathrm{~cm} ; O_{e}$ indicates soil with depth of $20-40 \mathrm{~cm}$, while $O_{a}$ means soils at the depth of $40-60 \mathrm{~cm}$.

\subsection{Sampling Method of Litterfall}

Litter traps $(1 \mathrm{~m} \times 1 \mathrm{~m})$ with the base bottom covered by perforated plastic sheets were randomly arranged in each forest plots ( $2 \mathrm{~m} \times 2 \mathrm{~m} /$ plot, five plots) in late October 2013 when was the largest amount of litterfall period of the studied subtropical forest. The litter bag technique was adopted to calculate the decomposition rates. The litters obtained by the traps were put in the acid-cleaned litter bags $(10 \mathrm{~cm} \times 10 \mathrm{~cm})$, with $10 \mathrm{~g}$ litters per bag. A total of $60 \mathrm{~L}$ bags were produced and randomly placed on the plantation floors of a larger plot of $20 \mathrm{~m} \times 20 \mathrm{~m}$ in October 2013. Mesh size of $1 \mathrm{~mm}$ was used, because free entry of small soil animals was allowed and microbial activities were kept. Finally, a total of $48 \mathrm{~L}$ bags containing decomposing litters were obtained from the forest floor for two years (724 days), with 2 bags monthly.

\subsection{Sample Analysis, Quality Control and Statistical Analysis}

In this study, all containers and tubes were rinsed thoroughly with ultra-pure water (Milli-Q integral 3, Millipore, France) after being soaked in dilute 10\% $(v / v) \mathrm{HNO}_{3}$ for $24 \mathrm{~h}$. Borosilicate containers, such as bottles and large-mouthed jars, were broiled at $500{ }^{\circ} \mathrm{C}$ for 40 minutes in a muffle furnace after soaking and rinsing, and then parceled by three PE preservation bags when they were cooling in a sealed ultra-pure testbed. Lastly, they were housed in a box to keep the temperatures of bottles and jars from getting too high. Especially, PE gloves were obliged to equip during all sampling.

$\mathrm{THg}$ and $\mathrm{MeHg}$ concentrations in the water samples were measured by the EPA Method 1631 and 1630 respectively $[28,29]$. THg concentrations in the leaf tissue were measured by cold vapor 
atomic absorption spectrophotometry (CVAAS) after a series of treatments, including acid digestion, oxidation, purge and trap [26]. THg concentrations in the soil were measured by a DMA-80 (Milestone, Sorisole, Italy) direct $\mathrm{Hg}$ analyzer, with detection limit of $0.005 \mathrm{ng}$. Standard reference material for soil component analysis, soils in Sichuan Basin (GBW07428/GSS-14, see www.gbw365.com) was used to make standard and calibration during the measurement of soil $\mathrm{THg}$. The concentrations of $\mathrm{MeHg}$ in the soil and leaf tissue were measured by cold vapor atomic fluorescence spectrophotometry (CVAFS) after a series of pre-treatments, such as digestion, extraction and back-extraction in accordance with EPA Method 1630. The mechanisms for measuring MeHg and EthylHg are based on the different separation coefficients of different species of $\mathrm{Hg}$ driven by carrier gas (high purity argon) in $\mathrm{Hg}$ analyzer.

The matrix spikes recoveries were $89 \%$ to $113 \%$ for $\mathrm{THg}$, and $91 \%$ to $116 \%$ for $\mathrm{MeHg}$ respectively. The average relative standard deviation for repeated analyses were $5.2 \%$ for $\mathrm{THg}$ and $5.4 \%$ for MeHg. The precisions of duplicate samples for THg in water, soil and leaf tissues were $5 \%, 9 \%$, and $4 \%$ respectively, while for $\mathrm{MeHg}, 4 \%, 7 \%$ and $8 \%$. The method blank for $\mathrm{THg}$ and $\mathrm{MeHg}$ were $0.05-0.1 \mathrm{ng} \mathrm{L}^{-1}$ and $0.03-0.01 \mathrm{ng} \mathrm{L}^{-1}$ respectively, which were both far lower than the sample concentrations. Student's two-tailed $t$-test is used for statistical analysis to determine whether two sets of data are significantly different from each other, with $p<0.05$ being considered as statistically significant.

\section{Results}

\subsection{Influence of the Forest Canopy on $\mathrm{Hg}$ Deposition through Throughfall and Litterfall}

Throughfall in the evergreen broadleaf forest possessed significantly higher THg concentrations than the open precipitation ( $p \leq 0.001, n=104)$. Mean concentrations of THg in the precipitation ranged from 3.1 to $38 \mathrm{ng} \mathrm{L}^{-1}$, and the overall VWM were $10.61 \pm 5.6 \mathrm{ng} \mathrm{L}^{-1}$ and $9.77 \pm 8.3 \mathrm{ng} \mathrm{L}^{-1}$ in the first and second year respectively (Table 2). Mean concentrations of THg in the throughfall ranged from 3.2 to $87.3 \mathrm{ng} \mathrm{L}^{-1}$ (Figure 2), and the average VWM was $21.28 \mathrm{ng} \mathrm{L}^{-1}$ (Table 2). Mean concentrations of $\mathrm{MeHg}$ in the direct wet deposition ranged from $0.09 \mathrm{ng} \mathrm{L}^{-1}$ to $0.75 \mathrm{ng} \mathrm{L}^{-1}$ (Figure 3), and the overall VWM was $0.19 \pm 0.13 \mathrm{ng} \mathrm{L}^{-1}$ (Table 2). Mean concentrations of $\mathrm{MeHg}$ in the throughfall ranged from $0.1 \mathrm{ng} \mathrm{L}^{-1}$ to $1.23 \mathrm{ng} \mathrm{L}^{-1}$ (Figure 3), averaging $0.24 \pm 0.20 \mathrm{ng} \mathrm{L}^{-1}$ (Table 2).

The average fluxes of THg in the litterfall ranged from $47.65 \mathrm{ng} \mathrm{L}^{-1}$ to $49.01 \mathrm{ng} \mathrm{L}^{-1}$ (Table 2), and the mean fluxes of $\mathrm{MeHg}$ in the litterfall collected from the studied forest from 2013 to 2015 ranged from $0.38 \mathrm{ng} \mathrm{L}^{-1}$ to $0.39 \mathrm{ng} \mathrm{L}^{-1}$ (Table 2).

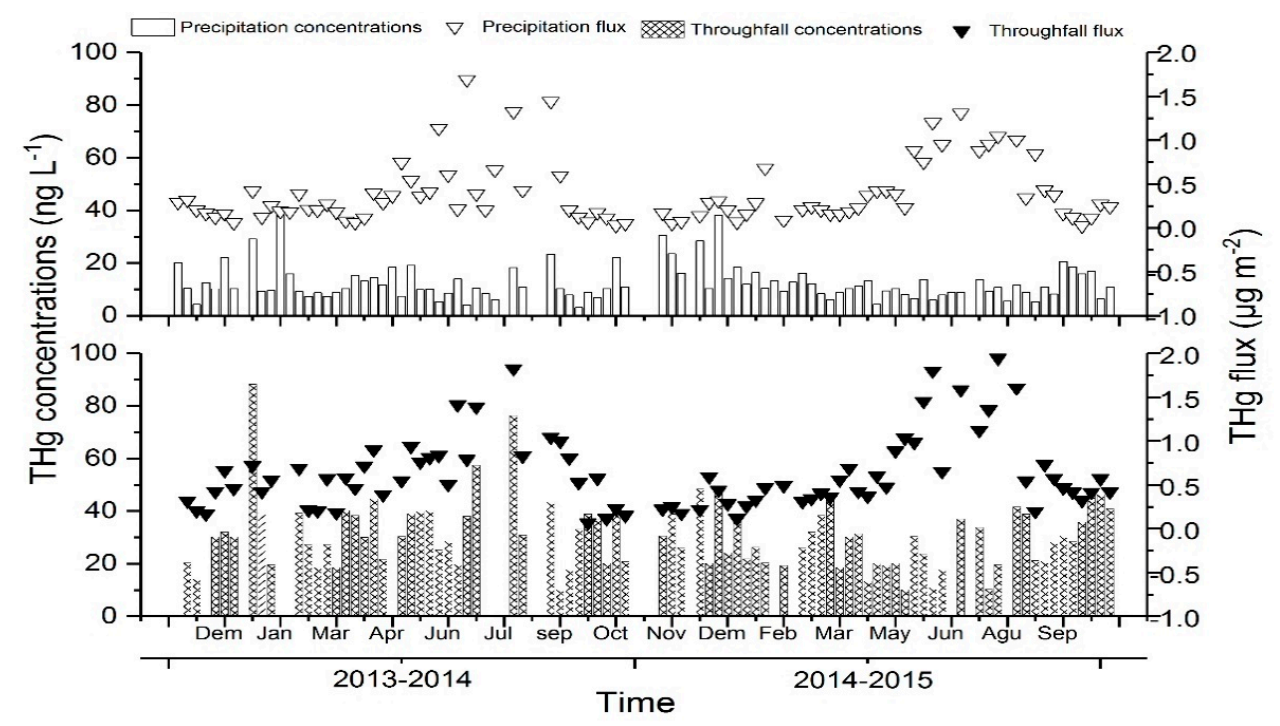

Figure 2. THg concentrations and fluxes in the precipitation and throughfall collected in the study forest stand from 2013 to 2015. 
Table 2. The corrected concentrations and fluxes of $\mathrm{THg}$ and $\mathrm{MeHg}$ in the throughfall, litterfall, runoff, forest-floor percolates and water during the sampling period from 2013 to 2015.

\begin{tabular}{|c|c|c|c|c|c|c|c|c|c|c|}
\hline \multirow[t]{3}{*}{ Samples } & \multicolumn{2}{|c|}{ THg Concentration } & \multicolumn{2}{|c|}{ MeHg Concentration } & \multicolumn{2}{|c|}{ Water/Litterfall Flux } & \multicolumn{2}{|c|}{ THg Flux } & \multicolumn{2}{|c|}{ Mehg Flux } \\
\hline & \multicolumn{4}{|c|}{$n g L^{-1}$} & \multicolumn{2}{|c|}{$\mathrm{mm}$} & \multicolumn{4}{|c|}{$\mu \mathrm{g} \mathrm{m}^{-2} \mathrm{yr}^{-1}$} \\
\hline & 2013-2014 & 2014-2015 & 2013-2014 & 2014-2015 & 2013-2014 & 2014-2015 & 2013-2014 & 2014-2015 & 2013-2014 & 2014-2015 \\
\hline Precipitation & $10.61 \pm 5.6$ & $9.77 \pm 8.3$ & $0.13 \pm 0.12$ & $0.11 \pm 0.13$ & 1395 & 1480 & 16.19 & 18.89 & 0.18 & 0.16 \\
\hline Throughfall & $22.14 \pm 4.9$ & $20.92 \pm 16.2$ & $0.20 \pm 0.08$ & $0.19 \pm 0.22$ & 1073 & 1188 & 22.34 & 24.35 & 0.23 & 0.22 \\
\hline Runoff & $20.32 \pm 9.1$ & $22.24 \pm 19.4$ & $0.31 \pm 0.19$ & $0.29 \pm 0.18$ & 861 & 884 & 19.93 & 21.66 & 0.27 & 0.26 \\
\hline Percolate $\left(O_{i}\right)$ & $45.59 \pm 12.1$ & $48.29 \pm 34.2$ & $0.26 \pm 0.12$ & $0.25 \pm 0.16$ & $582(834)$ & $602(850)$ & 8.03 & 10.20 & 0.22 & 0.21 \\
\hline Percolate $\left(O_{e}\right)$ & $55.84 \pm 10.2$ & $56.58 \pm 28.3$ & $0.21 \pm 0.16$ & $0.22 \pm 0.14$ & $584(896)$ & $610(867)$ & 10.54 & 11.95 & 0.15 & 0.16 \\
\hline Percolate $\left(O_{a}\right)$ & $51.05 \pm 25.5$ & $55.14 \pm 19.6$ & $0.19 \pm 0.11$ & $0.17 \pm 0.08$ & $591(808)$ & $604(829)$ & 9.27 & 10.04 & 0.15 & 0.14 \\
\hline \multirow{2}{*}{ Litterfall } & \multicolumn{4}{|c|}{$\operatorname{ng~g~}^{-1}$} & \multicolumn{2}{|c|}{$\mathrm{g} \mathrm{m}^{-2}$} & \multicolumn{4}{|c|}{$\mu \mathrm{g} \mathrm{m}^{-2} \mathrm{yr}^{-1}$} \\
\hline & $104.5 \pm 23.5$ & $106.3 \pm 18.7$ & $0.84 \pm 0.12$ & $0.83 \pm 0.20$ & 456 & 461 & 47.65 & 49.01 & 0.38 & 0.39 \\
\hline
\end{tabular}

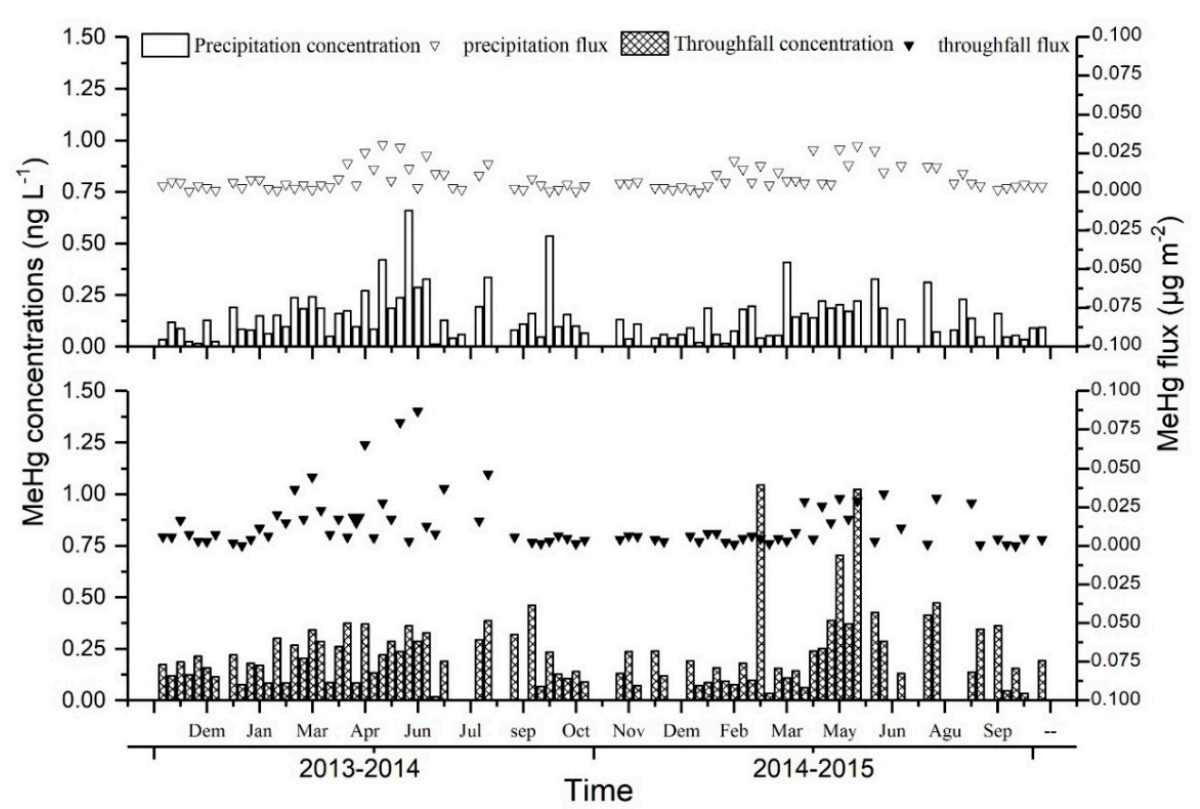

Figure 3. MeHg concentrations and fluxes in the precipitation and throughfall collected in the study forest stand from 2013 to 2015. 


\subsection{Dynamics of $\mathrm{Hg}$ in the Forest Runoff}

The variations of unfiltered $\mathrm{THg}$ and $\mathrm{MeHg}$ concentrations and fluxes in the forest runoff in Mt. Simian were shown in Table 2 and Figure 4. THg concentrations in the forest runoff varied between $11.3 \mathrm{ng} \mathrm{L}^{-1}$ and $40.7 \mathrm{ng} \mathrm{L}^{-1}$, with the VWM concentration of $21.28 \mathrm{ng} \mathrm{L}^{-1}$. The highest concentrations of MeHg in the runoff occurred mainly from May to July $\left(>0.15 \mathrm{ng} \mathrm{L}^{-1}\right)$, whereas $\mathrm{THg}$ concentrations in the runoff were elevated $\left(>20 \mathrm{ng} \mathrm{L}^{-1}\right.$ ) during the rainy season (June to September) (Figure 4). $\mathrm{THg}$ concentrations in the surface runoff were lower than that in the throughfall during the first year, while they were slightly higher than that in the throughfall in the second year.

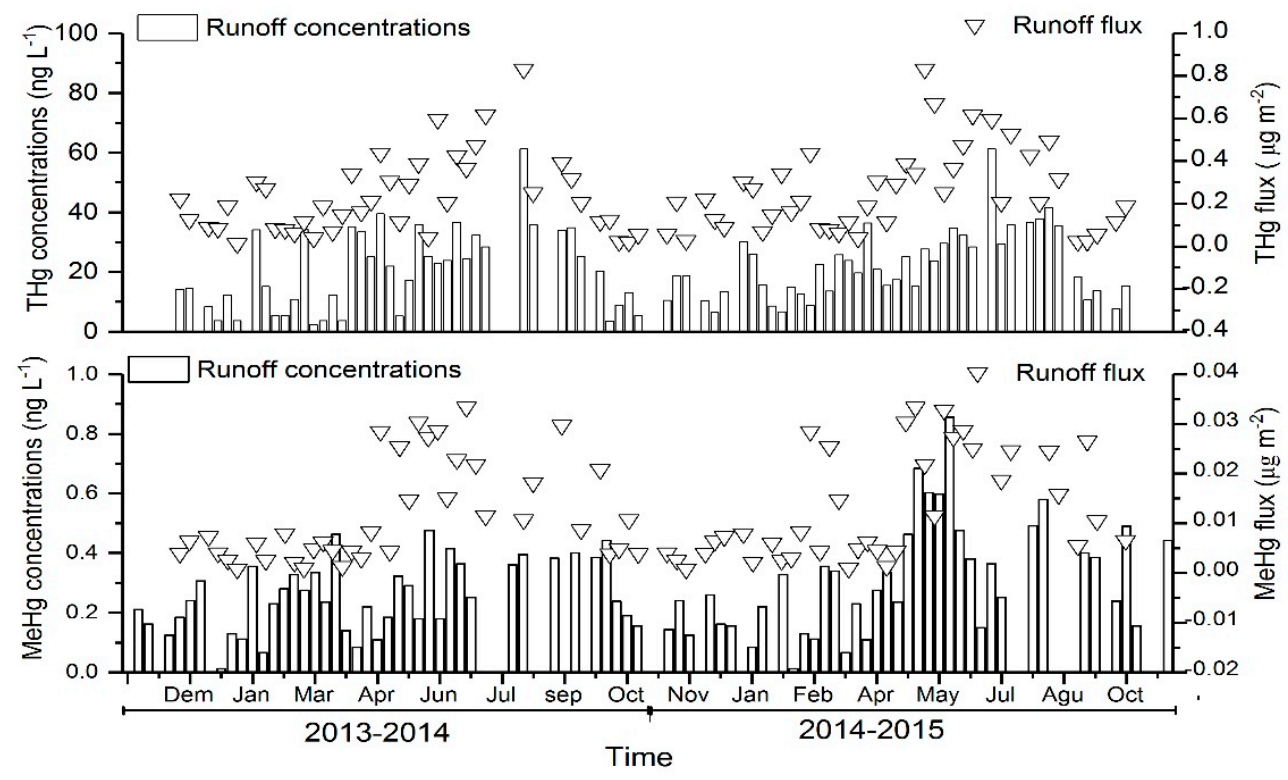

Figure 4. $\mathrm{THg}$ and $\mathrm{MeHg}$ concentrations and fluxes in the forest runoff collected in the study forest stand from 2013 to 2015.

\subsection{Dynamics of $\mathrm{Hg}$ in the Forest-Floor Percolates}

$\mathrm{THg}$ and $\mathrm{MeHg}$ fluxes and concentrations were lowest from December to March since it was in the dry season in the studied subtropical forest, characterized by lower temperatures and less rain comparing with other seasons (Figures 5 and 6). The correlation between the throughfall and THg fluxes was highly significant in all the layers $\left(O_{i}, O_{a}\right.$, and $O_{e}, p<0.001, t$-test). However, the difference of MeHg fluxes with the throughfall occurred only in the $O_{i}$ layer, while there was no significant difference in the $O_{a}$ layer. During the two-year monitoring period, the annual average THg flux in the infiltration water was highest in the $O_{e}$ layer (11.27), followed by $O_{a}(9.66)$ and $O_{i}(9.17)$ layers. One of the sources of $\mathrm{THg}$ in the $\mathrm{O}_{e}$ layer could be $\mathrm{Hg}$ in the precipitation or throughfall (Table 3).

The concentrations of MeHg was highest in spring, followed by summer and autumn, and lowest in winter. Two-tailed $t$-test results (assuming equal variance) showed that $\mathrm{MeHg}$ concentrations in the soil samples in spring had highly significant differences with that in the percolate samples $(p<0.001$, $t$-test), while the differences between the other seasons were not significant ( $p>0.05, t$-test). In autumn, after the plants withered owing to lowered temperatures, the litterfall accumulated $\mathrm{MeHg}$ temporarily. The fluxes of $\mathrm{MeHg}$ showed significant seasonal variations in soil leachate, particularly in the $O_{i}$ layer. The fluxes of $\mathrm{MeHg}$ in the leachate of $O_{i}$ layer of the forest soil in spring and summer were significantly higher than that in autumn and winter, and it was lowest in winter. Methylmercury began to accumulate since spring, and it was the highest during late spring and early summer. 


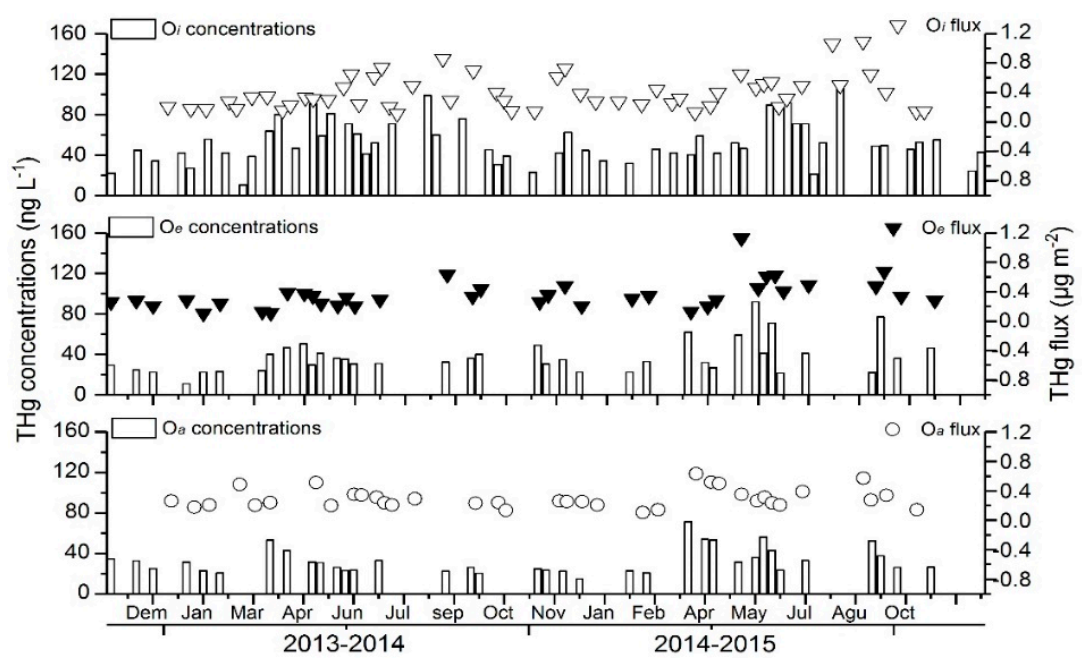

Figure 5. THg concentrations and fluxes in the soil percolates collected in the study forest stand from 2013 to 2015.

Table 3. The corrected concentrations and fluxes of $\mathrm{THg}$ and $\mathrm{MeHg}$ in the runoff, forest floor percolates and water during the sampling period from 2013 to 2015.

\begin{tabular}{|c|c|c|c|c|c|c|c|c|c|c|}
\hline \multirow{2}{*}{ Layer } & \multicolumn{2}{|c|}{ THg Concentration $\left(\mathrm{ng} \mathrm{L}^{-1}\right)$} & \multicolumn{2}{|c|}{ MeHg Concentration (ng L ${ }^{-1}$ ) } & \multicolumn{2}{|c|}{ Water/Litterfall Flux (mm) } & \multicolumn{2}{|c|}{ THg Flux $\left(\mu \mathrm{g} \mathrm{m}^{-2} \mathrm{yr}^{-1}\right)$} & \multicolumn{2}{|c|}{$\operatorname{MeHg}$ Flux $\left(\mu \mathrm{g} \mathrm{m}^{-2} \mathrm{yr}^{-1}\right.$} \\
\hline & 2013-2014 & 2014-2015 & 2013-2014 & 2014-2015 & 2013-2014 & 2014-2015 & 2013-2014 & 2014-2015 & 2013-2014 & 2014-2015 \\
\hline Runoff & $20.32 \pm 9.1$ & $22.24 \pm 19.4$ & $0.31 \pm 0.19$ & $0.29 \pm 0.18$ & 861 & 884 & 19.93 & 21.66 & 0.27 & 0.26 \\
\hline
\end{tabular}




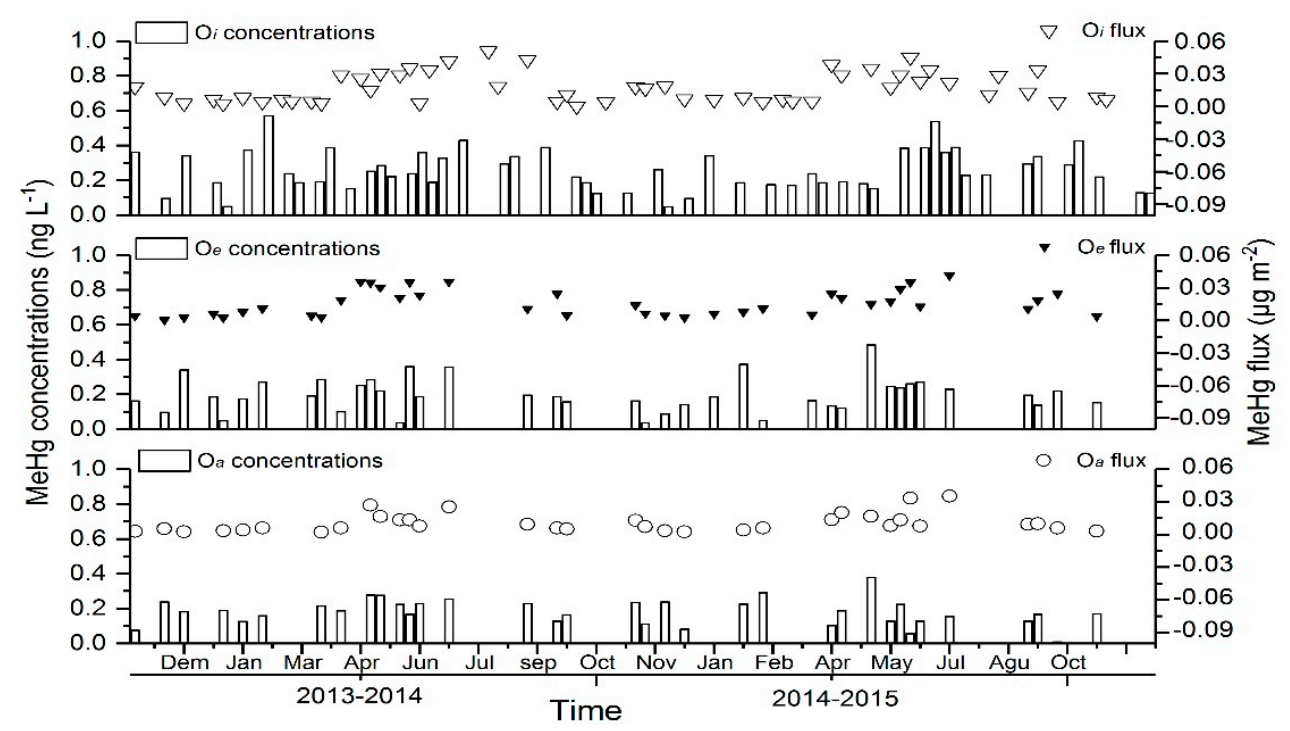

Figure 6. $\mathrm{MeHg}$ concentrations and fluxes in the soil percolates collected in the study forest stand from 2013 to 2015.

\section{Discussion}

\subsection{Influence of the Forest Canopy on Hg Deposition through Throughfall}

The VWM concentrations of THg and MeHg in the throughfall were found to be 2.0 and 1.3 times higher than those in the precipitation respectively during the experimental period. The concentrations of $\mathrm{MeHg}$ and $\mathrm{THg}$ in the net throughfall were not found to remarkably correspond with those in wet deposition of the open $\left(r^{2}=0.13\right)$, inferring that wet deposition was not the main driver for $\mathrm{Hg}$ fluxes in the throughfall, especially for THg. Here net throughfall means throughfall minus direct wet deposition. The variation tendency of $\mathrm{MeHg}$ concentrations in the throughfall was somewhat similar to THg. The two-year data indicated that forest canopy had great influence on the concentrations and fluxes of THg. The concentrations of $\mathrm{MeHg}$ in the throughfall were also significantly higher than that in the open bulk precipitation ( $p=0.003, n=107)$.

$\mathrm{THg}$ concentrations in the throughfall were found to be maximum from October to March (cold season), when the rainfall was less and atmospheric $\mathrm{Hg}$ concentrations were elevated. The cold season of the sampling site is principally controlled by the northwest monsoon, which generally brings less precipitation. Meanwhile, the cold season of China generally means higher atmospheric stability, which makes atmospheric Hg move difficultly. Therefore, the atmosphere in the cold season possesses higher Hg-scavenging abilities. Contrarily, the sampling site is mainly impacted by southeast monsoon from April to September (warm season), resulting in great increase of rainfall and lower concentrations of $\mathrm{Hg}$ (Figure 2).

THg fluxes in the throughfall of Mt. Simian was over 93\% enhancement, which was significantly higher than those reported from other places $[12,16,18,30]$. The reason is perhaps that atmospheric $\mathrm{Hg}$ accumulated in the vegetation via dry deposition is washed out by the throughfall. The transportation and deposition of atmospheric $\mathrm{Hg}$ is highly dependent on its speciation. It is widely accepted that highly soluble inorganic $\mathrm{Hg}\left(\mathrm{Hg}(\mathrm{II}), \mathrm{Hg}^{2+}\right)$ are rapidly stripped from the atmosphere and deposited locally, whereas aerosol $(\mathrm{Hg}-\mathrm{p})$ and elemental $\left(\mathrm{Hg}^{0}\right) \mathrm{Hg}$ emissions are transported regionally and globally respectively [30-33]. Therefore, the enhancement of THg concentration in the throughfall may indicate that the great loading of $\mathrm{Hg}$ in the upland forest comes from regional $\mathrm{Hg}$ emissions from industrial activities and coal combustion. Canopy density, on the other hand, played certain roles on the elevation of $\mathrm{THg}$ and $\mathrm{MeHg}$ concentrations. $\mathrm{THg}$ concentrations in the throughfall of the evergreen broadleaf forest with canopy densities over $93 \%$ were significantly higher than those obtained from other boreal forests of lower canopy densities [32,34]. 
Summarily, THg deposition fluxes at Mt. Simian were significantly higher than those reported from other places in Asia, Europe and North American [10,14,35,36]. Annual Hg flux through thoughfall in Mt. Simian is higher than that in Europe and North American $\left(2.1-40.1 \mu \mathrm{g} \mathrm{m}^{-2} \mathrm{yr}^{-1}\right)$. To sum up, the total $\mathrm{Hg}$ deposition fluxes through litterfall and throughfall in the subtropical forest of Mt. Simian is 2 to 10 times of the observation values in the temperate forests of Europe and North American [9,37-39]. The reason perhaps is that forest canopy density of the subtropical evergreen broadleaf forest of Mt. Simian reaches more than $98 \%$, which is exceedingly larger than other sites. More importantly, the increased Hg deposition fluxes over time is probably because of the elevated atmospheric $\mathrm{Hg}$ concentrations in the past decades for China's fast development. This could explain some of the discrepancy from background values observed in European and North American. Meanwhile, both higher $\mathrm{THg}$ and $\mathrm{MeHg}$ fluxes in the throughfall may lead to the accumulation of $\mathrm{Hg}$ in the soils of forest field [30], especially in the warm season (Figure 2).

\subsection{Influence of the Forest Canopy on Hg Deposition through Litterfall}

The average fluxes of $\mathrm{THg}$ and $\mathrm{MeHg}$ in the litterfall were considerably higher than those found in the forest ecosystems of Norway, Canada and the USA [13,14,16,30,40-42] and the global natural background value $\left(0.7-1.1 \mathrm{ng} \mathrm{m}^{-2} \mathrm{~h}^{-1}\right)$ [7]. Our results unequivocally illustrated that the forest canopy provided significant additional fluxes of both $\mathrm{MeHg}$ and $\mathrm{THg}$ to the forest ecosystems mainly through litterfall. As a matter of fact, the total fluxes of $\mathrm{MeHg}$ and $\mathrm{THg}$ under a standard 25-year old evergreen forest canopy at Mt. Simian is 2.2 and 2.4 times of those in the open. As we discussed above, the concentrations or fluxes of $\mathrm{Hg}$ in the litterfall appear to have correlation with the average atmospheric $\mathrm{Hg}$ levels in the local atmosphere. Numerous studies have demonstrated that elevated atmospheric $\mathrm{Hg}$ levels could promote the stomatal and nonstomatal uptake of $\mathrm{Hg}$ by the foliage $[13,35,36]$. As mentioned above that soluble $\mathrm{Hg}$ were easy to strip from the atmosphere and deposit locally, while aerosol emissions were transported regionally [14]. This result implies that a large majority of aerosol or reactive gaseous $\mathrm{Hg}$ were accumulated on the foliage via dry deposition in the study site. Therefore, our results further indicated that more serious atmospheric $\mathrm{Hg}$ pollution might contribute to greater fluxes to soils through throughfall and litterfall in the forest land, which was the same with previous results [38].

\subsection{Dynamics of $\mathrm{Hg}$ in the Forest Runoff}

THg concentrations in the surface runoff were generally higher in summer and autumn, but lower in winter. The underlying reason could possibly be that organisms (especially the flora and fauna) could decompose the organic matter in the litter and soil. Moreover, the mobility of released THg in the soil solution is affected by the soil moisture which is lower in the autumn and winter. Mercury as a heavy metal could also be directly adsorbed by the litter and soil, thereby reducing its activity [6,43-45]. Therefore, the exogenous input of $\mathrm{Hg}$ in the soil and litter would undergo a process of gradual accumulation. Mercury adsorbed and intercepted by leaves would eventually return to the forest soil owing to microbial decomposition of litter. However, the leaching of forest soil litter and organic matter causes great desorption effects on $\mathrm{Hg}$ in the soil. This might because that the solution in the organic matter contains a large amount of dissolved organic material (DOM). Previous studies have shown that since soil DOM contained a large number of functional groups, and they could form organometallic complexes with $\mathrm{Hg}$ by chelation, thus elevating the solubility of $\mathrm{Hg}$ [31,36]. In the litter and soil, the leaching of DOM towards heavy metals was particularly pronounced [46]. In addition, the increased amounts of $\mathrm{Hg}$ and active $\mathrm{Hg}$ in the newly settled litter could be fixed by a series of microbial activities during the decomposition process. This is particularly evident in the warm and humid summer, resulting in the accumulation of $\mathrm{Hg}$ in decayed leaf litter and soil humus layers, which could be washed away after the rain. The fluxes and concentrations of $\mathrm{Hg}$ in the surface runoff were temporally constant, unlike that in the precipitation and throughfall [47]. During heavy rainfall events, the precipitation and throughfall will dilute $\mathrm{Hg}$ in their respective environments, causing low 
$\mathrm{Hg}$ concentrations in the precipitation and throughfall. However, heavy rainfall resulted in high $\mathrm{Hg}$ fluxes. Furthermore, according to the characteristics of the surface runoff generation, the stronger the precipitation intensity, the greater the surface erosion. This phenomenon probably causes soluble $\mathrm{Hg}$ in the surface runoff to be larger, thereby increasing $\mathrm{Hg}$ fluxes [6,43-45].

$\mathrm{MeHg}$ concentrations in the surface runoff were significantly higher than that in the precipitation and throughfall. During the study period, higher values were recorded from April to June, which might be due to the warm and humid climate which favors microbial activities in the litter and soil, particularly those reductive anaerobic microorganisms. Mercury accumulated in decaying leaf litter could be absorbed or fixed by the litter with the help of microorganisms. Subsequently, this part of $\mathrm{Hg}$ could be transported into the soil in the form of residues and be covered by the subsequent batches of litter, forming a good anaerobic environment [13,48,49]. Coupled with warm and humid forest soil conditions, this could facilitate the production of $\mathrm{MeHg}$ in the decomposed litter, which migrates during the erosion by surface runoff. Consequently, $\mathrm{MeHg}$ concentrations were quite consistent with that in the surface runoff.

\subsection{Dynamics of Hg in the Forest-Floor Percolates}

Results indicated that the correlation between the throughfall and $\mathrm{THg}$ fluxes was highly significant in all the layers. It is known that water on the soil surface increased or reached saturation after raining, thereby causing water soluble $\mathrm{Hg}$ in the soil to move down gradually along with the soil solution into the $O_{e}$ layer. The permeability coefficients of $O_{i}$ and $O_{e}$ layers in the forest soils of Mt. Simian were $0.00602 \mathrm{~cm} \cdot \mathrm{s}^{-1}$ and $0.00153 \mathrm{~cm} \cdot \mathrm{s}^{-1}$ respectively. Obviously, the former was approximately four times of the latter. According to the characteristics of subsurface runoff generation, when the precipitation and throughfall intensities are both large, the forest soil percolate will produce two different forms of flows. One is at the interface between the $O_{i}$ layer and $O_{e}$ layers, and the other is at the interface between $O_{a}$ layer and the rock layer. The former flows fast and the latter is slow. With increasing flow, the former shows a trend of flowing slower than the latter. Therefore, $O_{e}$ layer had higher soluble $\mathrm{Hg}$ concentrations. Mercury in the throughfall and accumulated in the litter could have been absorbed by decomposed litter or fixed on the surface of leaf litter by microbial activities. Eventually, this part of $\mathrm{Hg}$ would enter into the forest soil in the form of residues and be covered by the subsequent batches of litter. However, if $\mathrm{Hg}$ in the lower soil layer and more readily decomposable litter migrated with the new litter and the fungal colony, this part of $\mathrm{Hg}$ would constitute the internal circulation mechanism of the forest, whereby the $\mathrm{Hg}$ will accumulate at the top layer of the soil. Thus, $\mathrm{Hg}$ transfer through the cross-section of the soil would be delayed, thereby increasing the retention time of $\mathrm{Hg}$ in the forest soil. As the leaves of trees and their litter eventually decompose and integrate with the soil, the $O_{e}$ and $O_{a}$ layers of the soil might store and enrich $\mathrm{Hg}$ in the forest ecosystem.

The concentrations of MeHg were highest in spring, followed by summer and autumn, and lowest in winter. It seemed that $\mathrm{MeHg}$ began to accumulate since spring, and it reached maximum in late spring and early summer. The reason could be that the decomposition rate of organic matter in newly settled litter was slow, and input of $\mathrm{Hg}$ through the litter was greater in autumn. However, the large amount of $\mathrm{Hg}$ input could probably convert to $\mathrm{MeHg}$ in the warm and humid spring and summer by a series of fixation and conversion by microorganisms [14]. As mentioned above that $\mathrm{Hg}$ in the throughfall and litter could be absorbed or fixed by the litter by microbial activities. Therefore, this part of $\mathrm{Hg}$ would eventually transform to the underlying soil in the form of residues, and then be covered by the subsequent fluttered litter. However, if $\mathrm{Hg}$ accumulated in the more readily decomposable litter and upper soil layer were fixed by microorganisms below the newly fallow litter, this part of $\mathrm{Hg}$ would circulate internally in the forest. Since $\mathrm{Hg}$ is accumulated in the lower layer of the litter and upper layer of the soil, its transfer through the soil cross-section is delayed, contributing to elevated retention time for $\mathrm{MeHg}$ in the forest soil that was easily eroded by the rainfall. 


\section{Conclusions}

The forest field exerts essential roles in the biogeochemical cycling of $\mathrm{THg}$ and $\mathrm{MeHg}$ in the forest ecosystems. It can be regarded as an effective converge for $\mathrm{MeHg}$ in the upper forest field, since only a small part of the deposited MeHg migrates into the lower soil layers. In contrast, $\mathrm{THg}$ retention is not consistent with $\mathrm{MeHg}$. This particular phenomenon indicates that the recovery of the forest floor from historical THg accumulation is delayed by an enhanced permeability and retention effect of the adsorption of $\mathrm{THg}$. Although there is different transferability of the two compounds in the forest floor and varied influencing factors influences their release between the runoff and percolate, these differences do not have a concurrent variation in the input-output budget of the entire ecological system at the interannual scale. However, it means that, for other factors of $\mathrm{MeHg}$ in the ecological system (like methylation in the litterfall), further research needs to be done to discover a more precise forecast model. Furthermore, it is not certain whether human $\mathrm{Hg}$ exposure exhibits via the runoff or interflow with the increasing accumulation of $\mathrm{Hg}$ in soil. The deposited $\mathrm{Hg}$, especially the $\mathrm{MeHg}$, gathered in the decomposing litter and upper soil, and the transfer of these two compounds by soil percolate has been delayed. This could increase the residence time of $\mathrm{MeHg}$ in the forest land once non-renewable harvesting of biomass contributes to deforestation and thus produces an ecological risk. In addition, there is not a systematic and precise study to explain the migration and transformation of $\mathrm{Hg}$ in forest watersheds due to the complexity of $\mathrm{Hg}$ geochemical behavior and the limitations of observation and experimental methods, as well as the imperfect parameterization schemes for models. Therefore, future work on establishing new technologies and methods for quantifying the storage, migration, and transformation of $\mathrm{Hg}$ in forest systems should be conducted in order to obtain more exact results.

Author Contributions: Conceptualization, M.M., Y.I. and D.W.; Methodology, M.M., T.S. and S.A. Software, H.D. and M.M. Formal analysis, H.D. and M.M.; Data curation, H.D. and M.M.; Writing-original draft preparation, M.M. and H. D; Writing-review and editing, H.D.; Visualization, D.W.; Supervision, M.M., Y.I. and D.W.; Funding acquisition, H.D., M.M., Y.I. and D.W.

Funding: This work was funded by the National Natural Science Foundation of China (No. 41573105, 41671469 \& 41603098), National Basic Research Program of China (973 Program, No. 2013CB430000), Recruitment Program of Foreign Experts (SWU118114), and the Natural Science Foundation of Chongqing (No. cstc2016jcyjA0461).

Conflicts of Interest: The authors declare no conflict of interest. The funders had no role in the design of the study; in the collection, analyses, or interpretation of data; in the writing of the manuscript, or in the decision to publish the results.

\section{References}

1. Write, L.P.; Zhang, L.; Cheng, I.; Aherne, J.; Wentworth, G.R. Impacts and effects indicators of atmospheric deposition of major pollutants to various ecosystems-A review. Aerosol Air Qual. Res. 2018, 18, $1953-1992$. [CrossRef]

2. Chen, W.K.; Li, T.C.; Sheu, G.R.; Lin, N.H.; Chen, L.Y.; Yuan, C.S. Correlation analysis, transportation mode of atmospheric mercury and criteria air pollutants, with meteorological parameters at two remote sites of mountain and offshore island in Asia. Aerosol Air Qual. Res. 2016, 16, 2692-2705. [CrossRef]

3. Feng, X.; Jiang, H.; Qiu, G.; Yan, H.; Li, G.; Li, Z. Geochemical processes of mercury in Wujiangdu and Dongfeng reservoirs, Guizhou, China. Environ. Pollut. 2009, 157, 2970-2984. [CrossRef] [PubMed]

4. Feng, X.; Jiang, H.; Qiu, G.; Yan, H.; Li, G.; Li, Z. Mercury mass balance study in Wujiangdu and Dongfeng Reservoirs, Guizhou, China. Environ. Pollut. 2009, 157, 2594-2603. [CrossRef] [PubMed]

5. Fu, X.; Feng, X.; Shang, L.; Wang, S.; Zhang, H. Two years of measurements of atmospheric total gaseous mercury (TGM) at a remote site in Mt. Changbai area, Northeastern China. Atmos. Chem. Phys. 2012, 12, 4215-4226. [CrossRef]

6. Grigal, D.F. Inputs and outputs of mercury from terrestrial watersheds: A review. Environ. Rev. 2002, 10, 1-39. [CrossRef]

7. Schroeder, W.H.; Munthe, J. Atmospheric mercury-An overview. Atmos. Environ. 1998, 32, 809-822. [CrossRef] 
8. Wright, L.P.; Zhang, L.; Marsik, F. Overview of mercury dry deposition, litterfall, and throughfall studies. Atmos. Chem. Phys. 2016, 16, 13399-13416. [CrossRef]

9. Zhang, L.; Wu, Z.; Cheng, I.; Wright, L.P.; Olson, M.L.; Gay, D.A.; Risch, M.R.; Brooks, S.; Castro, M.S.; Conley, G.D.; et al. The estimated six-year mercury dry deposition across North America. Environ. Sci. Technol. 2016, 50, 12864-12873. [CrossRef] [PubMed]

10. Feng, X.; Yan, H.; Sf Qiu, G.; Tang, S.; Shang, L.; Dai, Q.; Hou, Y. Seasonal variation of gaseous mercury exchange rate between air and water surface over Baihua reservoir, Guizhou, China. Atmos. Environ. 2004, 38, 4721-4732. [CrossRef]

11. Schlüter, K. Review: Evaporation of mercury from soils. An integration and synthesis of current knowledge. Environ. Geol. 2000, 39, 249-271. [CrossRef]

12. Rea, A.W.; Lindberg, S.E.; Keeler, G.J. Dry deposition and foliar leaching of mercury and selected trace elements in deciduous forest throughfall. Atmos. Environ. 2001, 35, 3453-3462. [CrossRef]

13. St Louis, V.L.; Rudd, J.W.; Kelly, C.A.; Hall, B.D.; Rolfhus, K.R.; Scott, K.J.; Lindberg, S.E.; Dong, W. Importance of the forest canopy to fluxes of methyl mercury and total mercury to boreal ecosystems. Environ. Sci. Technol. 2001, 35, 3089-3098. [CrossRef] [PubMed]

14. Demers, J.D.; Driscoll, C.T.; Fahey, T.J.; Yavitt, J.B. Mercury cycling in soil and litter in different forest types in the Adirondack region, New York, USA. Ecol. Appl. A Publ. Ecol. Soc. Am. 2007, 17, 1341-1351. [CrossRef]

15. Huang, J.; Kang, S.; Zhang, Q.; Guo, J.; Chen, P.; Zhang, G.; Tripathee, L. Atmospheric deposition of trace elements recorded in snow from the Mt. Nyainqêntanglha region, southern Tibetan Plateau. Chemosphere 2013, 92, 871-881. [CrossRef] [PubMed]

16. Landis, M.S.; Keeler, G.J. Atmospheric mercury deposition to lake Michigan during the lake Michigan mass balance study. Environ. Sci. Technol. 2002, 36, 4518-4524. [CrossRef] [PubMed]

17. Pacyna, E.G.; Pacyna, J.M.; Steenhuisen, F.; Wilson, S. Global anthropogenic mercury emission inventory for 2000. Atmos. Environ. 2006, 40, 4048-4063. [CrossRef]

18. Yu, B.; Fu, X.; Yin, R.; Zhang, H.; Wang, X.; Lin, C.J.; Wu, C.; Zhang, Y.; He, N.; Fu, P. Isotopic composition of atmospheric mercury in China: New evidence for source and transformation processes in air and in vegetation. Environ. Sci. Technol. 2016, 50, 9262-9269. [CrossRef] [PubMed]

19. Wang, B.; Zhang, H.; Xu, L.; Wang, W.; Wei-Li, L.U.; Meng, L. Reserves and water capacity characteristics of different species of litter in Simian Mountain. J. Soil Water Conserv. 2008, 22, 90-93. (In Chinese)

20. Branfireun, B.A.; Hilbert, D.; Roulet, N.T. Sinks and sources of methylmercury in a boreal catchment. Biogeochemistry 1998, 41, 277-291. [CrossRef]

21. Shanley, J.B.; Kamman, N.C.; Clair, T.A.; Chalmers, A. Physical controls on total and methylmercury concentrations in streams and lakes of the northeastern USA. Ecotoxicology 2005, 14, 125-134. [CrossRef] [PubMed]

22. Watras, C.J.; Morrison, K.A.; Kent, A.; Price, N.; Regnell, O.; Eckley, C.; Hintelmann, H.; Hubacher, T. Sources of methylmercury to a wetland-dominated lake in northern Wisconsin. Environ. Sci. Technol. 2005, 39, 4747-4758. [CrossRef] [PubMed]

23. Gustin, M.S.; Lindberg, S.E.; Weisberg, P.J. An update on the natural sources and sinks of atmospheric mercury. Appl. Geochem. 2008, 23, 482-493. [CrossRef]

24. Pan, Y.; Birdsey, R.A.; Phillips, O.L.; Jackson, R.B. The Structure, distribution, and biomass of the world's forests. Annu. Rev. Ecol. Evol. S. 2013, 44, 593-622. [CrossRef]

25. Ma, M.; Wang, D.; Sun, T.; Zhao, Z.; Du, H. Forest runoff increase mercury output from subtropical forest catchments: An example from an alpine reservoir in a national nature reserve (southwestern China). Environ. Sci. Pollut. Res. 2015, 22, 2745-2756. [CrossRef] [PubMed]

26. Ma, M.; Wang, D.; Du, H.; Sun, T.; Zhao, Z.; Wei, S. Atmospheric mercury deposition and its contribution of the regional atmospheric transport to mercury pollution at a national forest nature reserve, southwest China. Environ. Sci. Pollut. Res. 2015, 22, 20007-20018. [CrossRef] [PubMed]

27. Schwesig, D.; Matzner, E. Dynamics of mercury and methylmercury in forest floor and runoff of a forested watershed in central Europe. Biogeochemistry 2001, 53, 181-200. [CrossRef]

28. USEPA. Method 1631: Revision E: Mercury in Water by Oxidation, Purge and Traps, and Cold Vapor Atomic Fluorescence Spectrometry; USEPA: Washington, DC, USA, 2002. 
29. USEPA. Method 1630: Methyl Mercury in Water by Distillation, Aqueous Ethylation, Purge and Trap and CVAFS; USEPA: Washington, DC, USA, 2001.

30. Larssen, T.; de Wit, H.A.; Wiker, M.; Halse, K. Mercury budget of a small forested boreal catchment in southeast Norway. Sci. Total Environ. 2008, 404, 290-296. [CrossRef] [PubMed]

31. Fu, X.; Feng, X.; Zhu, W.; Rothenberg, S.; Yao, H.; Zhang, H. Elevated atmospheric deposition and dynamics of mercury in a remote upland forest of southwestern China. Environ. Pollut. 2010, 158, 2324-2333. [CrossRef] [PubMed]

32. Ma, M.; Wang, D.; Du, H.; Sun, T.; Zhao, Z.; Wang, Y.; Wei, S. Mercury dynamics and mass balance in a subtropical forest, southwestern China. Atmos. Chem. Phys. 2016, 16, 4529-4537. [CrossRef]

33. Wang, D.; He, L.; Wei, S.; Feng, X. Estimation of mercury emission from different sources to atmosphere in Chongqing, China. Sci. Total Environ. 2006, 366, 722-728. [CrossRef] [PubMed]

34. Wang, S.; Xing, D.; Wei, Z.; Jia, Y. Spatial and seasonal variations in soil and river water mercury in a boreal forest, Changbai Mountain, Northeastern China. Geoderma 2013, 206, 123-132. [CrossRef]

35. Almeida, M.D.; Marins, R.V.; Paraquetti, H.H.M.; Bastos, W.R.; Lacerda, L.D. Mercury degassing from forested and open field soils in Rondônia, Western Amazon, Brazil. Chemosphere 2009, 77, 60-66. [CrossRef] [PubMed]

36. Silva-Filho, E.V.; Machado, W.; Oliveira, R.R.; Sella, S.M.; Lacerda, L.D. Mercury deposition through litterfall in an Atlantic forest at Ilha Grande, Southeast Brazil. Chemosphere 2006, 65, 2477-2484. [CrossRef] [PubMed]

37. Cole, A.S.; Steffen, A.; Eckley, C.S.; Narayan, J.; Pilote, M.; Tordon, R.; Graydon, J.A.; St Louis, V.L.; Xu, X.; Branfireun, B.A. A survey of mercury in air and precipitation across Canada: Patterns and trends. Atmosphere 2014, 5, 635-668. [CrossRef]

38. Driscoll, C.T.; Mason, R.P.; Chan, H.M.; Jacob, D.J.; Pirrone, N. Mercury as a global pollutant: Sources, pathways, and effects. Environ. Sci. Technol. 2013, 47, 4967-4983. [CrossRef] [PubMed]

39. Monson, B.A.; Staples, D.F.; Bhavsar, S.P.; Holsen, T.M.; Schrank, C.S.; Moses, S.K.; McGoldrick, D.J.; Backus, S.M.; Williams, K.A. Spatiotemporal trends of mercury in walleye and largemouth bass from the Laurentian Great Lakes region. Ecotoxicology 2011, 20, 1555-1567. [CrossRef] [PubMed]

40. Artaxo, P.; Campos, R.C.D.; Fernandes, E.T.; Martins, J.V.; Xiao, Z.; Lindqvist, O.; Maenhaut, W. Large scale mercury trace element measurements in the Amazon basin. Atmos. Environ. 2000, 34, 4085-4096. [CrossRef]

41. Choi, H.D.; Holsen, T.M. Gaseous mercury fluxes from the forest floor of the Adirondacks. Environ. Pollut. 2009, 157, 592-600. [CrossRef] [PubMed]

42. Ferrara, R.; Maserti, B.E.; Andersson, M.; Edner, H.; Ragnarson, P.; Svanberg, S. Mercury degassing rate from mineralized areas in the Mediterranean basin. Water Air Soil Pollut. 1997, 93, 59-66. [CrossRef]

43. Blackwell, B.D.; Driscoll, C.T. Deposition of mercury in forests along a montane elevation gradient. Environ. Sci. Technol. 2015, 49, 5363-5370. [CrossRef] [PubMed]

44. Blackwell, B.D.; Driscoll, C.T.; Maxwell, J.A.; Holsen, T.M. Changing climate alters inputs and pathways of mercury deposition to forested ecosystems. Biogeochemistry 2014, 119, 215-228. [CrossRef]

45. Laacouri, A.; Nater, E.A.; Kolka, R.K. Distribution and uptake dynamics of mercury in leaves of common deciduous tree species in Minnesota, U.S.A. Environ. Sci. Technol. 2013, 47, 10462-10470. [CrossRef] [PubMed]

46. Ci, Z.; Peng, F.; Xue, X.; Zhang, X. Air-surface exchange of gaseous mercury over permafrost soil: An investigation at a high-altitude (4700 m.a.s.l.) and remote site in the central Qinghai-Tibet Plateau. Atmos. Chem. Phys. 2016, 16, 14741-14754. [CrossRef]

47. Wang, X.; Luo, J.; Yin, R.; Yuan, W.; Lin, C.J.; Sommar, J.; Feng, X.; Wang, H.; Lin, C. Using mercury isotopes to understand mercury accumulation in the montane forest floor of the eastern Tibetan Plateau. Environ. Sci. Technol. 2016, 51, 801-809. [CrossRef] [PubMed]

48. Ericksen, S.M.; Schorran, D.E.; Johnson, D.W.; Lindberg, S.E.; Coleman, J.S. Accumulation of atmospheric mercury in forest foliage. Atmos. Environ. 2003, 37, 1613-1622. [CrossRef]

49. Stamenkovic, J.; Gustin, M.S. Nonstomatal versus stomatal uptake of atmospheric mercury. Environ. Sci. Technol. 2009, 43, 1367-1372. [CrossRef] [PubMed]

(C) 2018 by the authors. Licensee MDPI, Basel, Switzerland. This article is an open access article distributed under the terms and conditions of the Creative Commons Attribution (CC BY) license (http:/ / creativecommons.org/licenses/by/4.0/). 